\title{
Tumor targeting via integrin ligands
}

\section{Udaya Kiran Marelli ${ }^{1}$, Florian Rechenmacher ${ }^{1}$, Tariq Rashad Ali Sobahi ${ }^{2}$, Carlos Mas-Moruno ${ }^{3}$ and Horst Kessler ${ }^{1,2}$ *}

1 Institute for Advanced Study (IAS) and Center for Integrated Protein Science (CIPSM), Department Chemie, Technische Universität München, Garching, Germany

2 Department of Chemistry, Faculty of Science, King Abdulaziz University, Jeddah, Saudi Arabia

${ }^{3}$ Biomaterials, Biomechanics and Tissue Engineering Group, Department of Materials Science and Metallurgical Engineering, Technical University of Catalonia (UPC), Barcelona, Spain

\section{Edited by:}

Angelo Corti, San Raffaele Scientific Institute, Italy

\section{Reviewed by:}

Angelo Corti, San Raffaele Scientific Institute, Italy

Fabrizio Marcucci, Istituto Superiore di Sanità, Italy

\section{*Correspondence:}

Horst Kessler, Institute for Advanced Study (IAS) and Center for Integrated Protein Science (CIPSM), Department Chemie, Technische Universität München, Lichtenbergstrasse 4, 85747 Garching, Germany

e-mail: kessler@tum.de
Selective and targeted delivery of drugs to tumors is a major challenge for an effective cancer therapy and also to overcome the side-effects associated with current treatments. Overexpression of various receptors on tumor cells is a characteristic structural and biochemical aspect of tumors and distinguishes them from physiologically normal cells. This abnormal feature is therefore suitable for selectively directing anticancer molecules to tumors by using ligands that can preferentially recognize such receptors. Several subtypes of integrin receptors that are crucial for cell adhesion, cell signaling, cell viability, and motility have been shown to have an upregulated expression on cancer cells. Thus, ligands that recognize specific integrin subtypes represent excellent candidates to be conjugated to drugs or drug carrier systems and be targeted to tumors. In this regard, integrins recognizing the RGD cell adhesive sequence have been extensively targeted for tumor-specific drug delivery. Here we review key recent examples on the presentation of RGD-based integrin ligands by means of distinct drug-delivery systems, and discuss the prospects of such therapies to specifically target tumor cells.

Keywords: integrins, RGD, tumor, targeted delivery, $\alpha v \beta 3, \alpha v \beta 5, \alpha 5 \beta 1$ and $\alpha v \beta 6$

\section{INTRODUCTION}

Cancer diagnosis, therapy, and monitoring represent fundamental topics of research in medicine and are of utmost importance in healthcare of today's society. An efficient cancer therapy should possess exceptional abilities not only to ensure a complete removal

Abbreviations: A549, human non-small cell lung carcinoma; ATCC, CCL-185 cells; ATCC, HTB-65 cells; bFGF, basic fibroblast growth factor; BMEC, brain microvascular endothelial cells; Cap-RGD, Ac-CCVVVTGRGDSPSSK-COOH; DCP-TEPA, dicetylphosphate-tetraethylenepentamine; DOPE, dioleoylphosphatidylethanolamine; DPPC, 1,2-dipalmitoyl-sn-glycero-3-phosphocholine; DSPC, distearoylphosphatidylcholine; DSPE, distearoylphosphatidylethanolamine; DTPA, diethylenetriamenepentaacetate; FDG, fluoro-2-deoxy-D-glucose; HEK, human embryonic kidney; HeLa, human cervical carcinoma cells; HPAE-coPLA/DPPE, poly[(amine-ester)-co-(D,L-lactide)]/1,2-dipalmitoyl-sn-glycero-3phosphoethanolamine copolymer; HPMA, $N$-(2-hydroxypropyl)methacrylamide; HAS, human serum albumin; HUVEC, human umbilical vein endothelial cells; IV, intravenous; Luc-pDNA, luciferase pDNA; Mal-PEG-PCL, maleimidepoly(ethylene glycol)-block-poly( $\varepsilon$-caprolactone); MDR, multi-drug resistance; MeWo, human malignant skin melanoma; MMAE, monomethyl-auristatin-E; MRI, magnetic resonance imaging; NSCLC, non-small cell lung cancer; PCL-PEEP, poly( $\varepsilon$-caprolactone)-block-poly-(ethyl ethylene phosphate); pCMVLuc, Photinus pyralis luciferase under control of the CMV enhancer/promoter; PEG, polyethylene glycol; PEI, polyethylenimine; PEO-b-PCL, poly(ethylene oxide)-block-poly( $\varepsilon$ caprolactone); PET, positron emission tomography; PGA, poly-glutamic acid; PLA, poly(lactic acid); PLG, poly-L-glutamic acid; PLGA, poly (D,L-lactide-co-glycolide); PLL, poly (L-lysine); PLys, polylysine; pORF-hTRAIL, plasmid expressing the tumor necrosis factor-related apoptosis-inducing ligand (TRAIL); P(PEGMEMA), poly[poly(ethylene glycol) methyl ether methacrylate]; sFlt-1, soluble fms-like tyrosinekinase-1 (pDNA encoding the soluble form of VEGF receptor-1); SPECT, single-photon emission computed tomography; TAT peptide, CGRKKRRQRRR; Tf, transferrin; TfR, transferrin receptor; TLT, transplantable liver tumors; VEGF, vascular endothelial growth factors. of the tumor but also to prevent its spreading and invasion to other tissues by metastasis. Current clinical approaches to treat cancer include, and often combine, surgery, chemotherapy, radiation therapy as well as immunotherapy. However, these methods in general still fail to treat highly aggressive metastatic cancers, and present some serious limitations. For instance, irradiation of tumors may damage adjacent healthy tissues, and chemotherapy, which is based on a non-specific systemic distribution regime, requires high drug dosage and promotes severe adverse side effects. For example, the administration of Paclitaxel (PTX), a drug used for the treatment of lung, ovarian, and breast cancers, has been associated with unwanted effects such as hypersensitivity reactions, myelosuppression, and neurotoxicity $(1,2)$, among others. Doxorubicin (DOX), another drug used in cancer chemotherapy, has also been described to have cardiotoxic side effects $(3,4)$. Moreover, chemotherapy might turn inefficient due to acquired chemoresistance as exemplified in the case of Gemcitabine - prime therapeutic used to treat pancreatic cancers (5), for DOX (3) and also for PTX $(6,7)$.

Tumor targeted drug-delivery (Figure 1) represents a promising approach to overcome some of the above mentioned limitations (8). This strategy aims to specifically guide and direct anticancer therapeutics (or imaging agents) to tumor cells without interfering with normal tissues. Such targeted approach relies on the fact that tumor vasculature and tumor cells display a well-differentiated pattern of (over-)expression of specific receptors (i.e., receptors required for tumor angiogenesis), which is consistent with the concept of "Vascular Zip Codes" $(9,10)$. Targeted drug-delivery methods hence employ small molecules or 


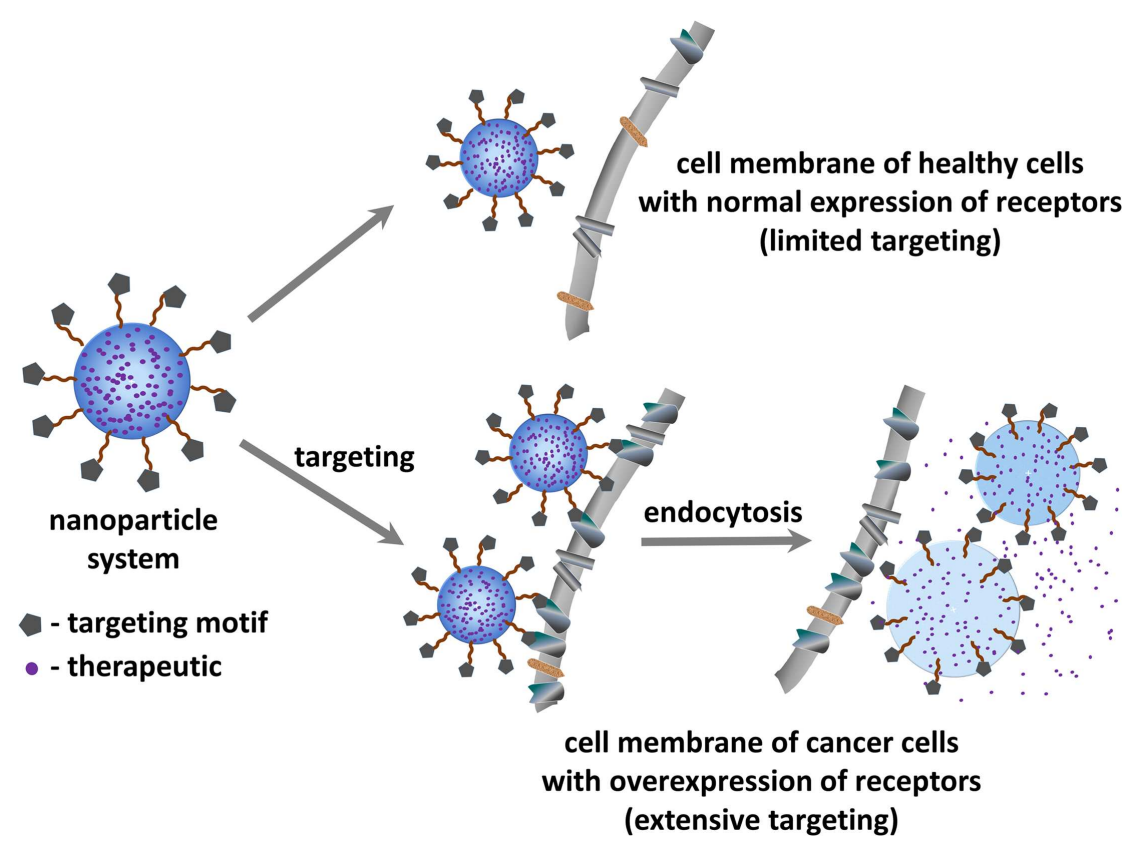

FIGURE 1 | Schematic representation of the principle of tumor targeted drug delivery for treating cancer.

A

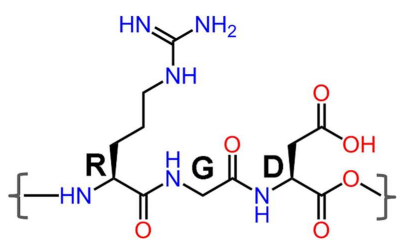

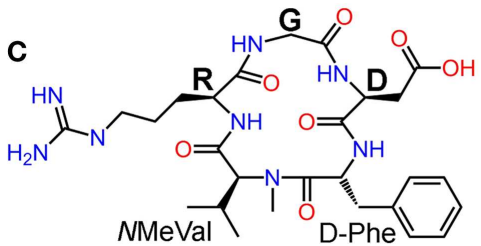

B

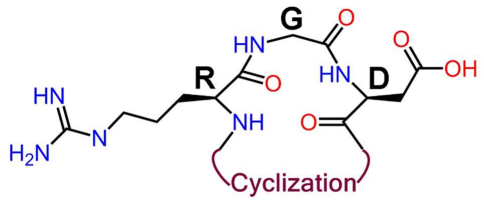

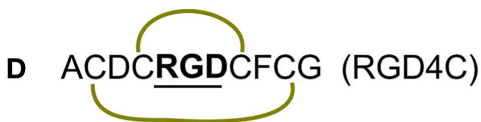

KSSPHSRN(SG) $)_{5}$ RGDSP (PR_b)

NAVPNLRGDLQVLAQKVART (A20FMDV2)

FIGURE 2 | (A) Integrin recognition motif RGD; (B) schematic representation of cyclic RGD (cRGD); (C) Cilengitide - c(RGDf-NMeVal); (D) peptide sequences of RGD4C (the green curves indicate disulfide bridges), $\alpha 5 \beta 1$ ligand PR_b, and $\alpha \mathrm{v} \beta 6$ ligand A20FMDV2.

monoclonal antibodies selective to receptors that are proven to be abnormally expressed on tumors. The conjugation of anticancer drugs to these selective ligands will allow a preferential or selective delivery of the drug to the tumor.

As a result, this technique benefits from several advantages: (i) non-specific interactions with normal tissues are reduced, and thus the adverse side-effects associated to conventional chemotherapy can be minimized. (ii) Site-directed drug release leads to higher local concentrations at the diseased tissue and thus allows dosage reduction. (iii) Acquired chemoresistance can potentially be reduced by co-delivering other therapeutics capable of regulating cancer multi-drug resistance (MDR). To avail these advantages, well accessible cell surface receptors are preferred over intracellular targets where (complex) drug internalization mechanisms need to be taken into consideration. In this regard, one of the most intensely referred class of proteins for targeted therapy is the integrin family (11).

Integrins are heterodimeric transmembrane glycoproteins consisting of an $\alpha$ and a $\beta$ subunit. In total, 24 different subtypes of integrins that are constituted from $18 \alpha$ and $8 \beta$ subunits have been discovered to date (12). Almost half of them bind to various extra cellular matrix (ECM) proteins such as fibronectin, vitronectin, and collagen through the tripeptide motif Arg-Gly-Asp = RGD [(13), Figure 2], and are vital in the adhesion, signaling, migration, and survival of most cells (14). Integrins have also very important roles in cancer progression and some subtypes have been described to be highly over-expressed on many cancer cells. This is the case of integrins $\alpha \mathrm{v} \beta 3$, $\alpha \mathrm{v} \beta 5$, and $\alpha 5 \beta 1$, which are crucial mediators 
of angiogenesis in cancer $(8,15-17)$. Underlying cause for this is the elevated demand by the enlarging tumor for adequate supply of necessary nutrients and oxygen. In order to meet these demands through blood supply, tumor tissue with a rapidly overgrowing number of cells, signals [via growth factors like vascular endothelial growth factor (VEGF) or basic fibroblast growth factor (bFGF)] for increased angiogenesis, a state known as "angiogenic switch." Sprouting of new blood vessels and overexpression of integrins in tumor tissues and vasculature are thus key features in the pathophysiology of cancer. Other integrins such as $\alpha v \beta 6$ and $\alpha 6 \beta 4$ are also observed to be expressed on tumor cells (8). Another pivotal function of integrins is the promotion of cell migration by virtue of their binding to ECM components. This phenomenon is responsible for the process of tumor proliferation, migration, invasion, and metastasis (18). These functional aspects together with the high expression levels found on tumor cells have converted integrins into very interesting proteins for targeted cancer diagnosis and therapy studies.

Our review shortly recapitulates recent developments in integrin targeted cancer therapy, with special focus on targeted delivery of chemotherapy or gene therapy via non-viral vectors like nanoparticles (NPs), micelles, vesicles, or other systems grafted with RGD-based integrin ligands. Considering the vastness of the topic, we have only cited a limited amount of recent works. For previous studies and developments in this field other detailed reviews are available (19-22). Applications based on integrin targeting antibodies and therapies involving the blocking of integrin functions with antagonists and other ligands are not subject of this review.

\section{INTEGRIN LIGANDS AND INTEGRIN TARGETING}

Since the discovery of the integrin recognizing RGD motif by Ruoslahti et al. $(13,23)$, extensive research has been carried out to develop RGD-based peptide and peptidomimetic integrin ligands (24). Various synthetic strategies have been applied to develop RGD peptide analogs with enhanced biological properties and pharmacokinetics like affinity and selectivity for different integrin subtypes, metabolic stability, and biodistribution. These strategies include the introduction of amino acids flanking the tripeptidic RGD sequence, cyclization, and variation of stereochemical configuration of the constituent amino acids (25), and N-methylation $(26,27)$ (Figure 2). Cilengitide $-c$ (RGDf$\mathrm{NMeVal}$ ) (Figure 2), a very potent antagonist of $\alpha \mathrm{v} \beta 3$, was developed by using some of these approaches and has been clinically tested by Merck primarily for treatment of glioblastoma multiforme $(28,29)$. Despite promising preliminary data, its use as anticancer therapeutic has been discontinued due to failure in phase-III clinical trials (Merck press release on Cilengitide studies: http://www.merck.de/de/presse/extNewsDetail.html?newsId= C47977D13865FCB9C1257B1D001EF9CA\&newsType=1). Other well-known RGD peptides are $c$ RGDfV (25) - the parent peptide for Cilengitide, $c$ RGDfK (30), and RGD4C (ACDCRGDCFCG) (31). RGD4C is susceptible to be expressed by recombinant methods into proteins and viruses for their targeted delivery. Targeting integrins using $c \mathrm{RGDfX}, c \mathrm{RGDeV}, c \mathrm{RGDyV}$, and other peptides or peptidomimetics (Figure 2) has also been reported in the literature.

\section{TARGETED DRUG DELIVERY}

Targeted delivery can be accomplished by two approaches: the direct conjugation of the targeting motif to the drug or the use of drug vehicular systems grafted with the targeting motif. Of these, the use of carrier systems offers several advantages compared to direct conjugation methods:

1. Carrier systems have the capacity to present multiple ligands on each particle. This facilitates effective targeting via multiple and simultaneous interactions between the ligands and the receptors, exploiting the concept of multivalency.

2. Vehicular systems may keep the drug unexposed to physiological systems, thereby protecting it from degradation or alteration, and more importantly, minimizing undesirable nonspecific interactions of the drug with normal tissues. Therefore, these systems may remarkably reduce the side effects of the drug.

3. Targeted carrier systems usually are internalized via receptormediated endocytosis and the drug is directly released within cell. This is more effective to attain higher in-cell drug concentrations for amplified therapeutic activity.

4. Being larger in size $(\sim>100 \mathrm{~nm})$ than classical drugs, carrier systems are not filtered off by renal pathways (size limit for renal filtration $\sim 5 \mathrm{~nm}$ ). This enables a prolonged half-life time of carrier particles in the blood stream and allows for a gradual release of the drug over longer periods of time. Such release kinetics avoid high systemic concentrations of the drug and improves the effectiveness of the administered dose.

5. The abnormal architecture and permeability of tumor vasculature promotes extravasation of the particles that are in blood circulation. This phenomenon is called enhanced permeability and retention (EPR) effect. Facilitated by this passive transport mechanism, the nano-sized vehicular systems enter into tumor tissues. However, the quick clearance of these NPs from the tissue is prevented by their large size and lead to prolonged retention times in tumor. Hence, the double targeting - passive and active receptor-mediated targeting, enhances therapeutic efficacy.

Among the carrier systems, viral vectors such as retroviruses and adenoviruses have been successfully developed and found to be efficient in targeted gene therapy (32). However, their use is associated with several disadvantages that have precluded their clinical application. In the first place, they can produce unwanted immune responses (33). Also, it is not easy to express viruses composed with targeting moieties that contain unnatural amino acids or chemically modified scaffolds. Moreover, viral vectors can only be used for gene therapy and are not suitable for delivery of chemotherapeutics. Last but not least, they also carry a negative public perception concerning safety $(33,34)$. Therefore, development of non-viral targeting vectors is a preferred alternative in targeted therapy. In this regard, various kinds of polymer-based nanocarriers have been developed for tumor targeting using integrin ligands including the use of RGD coated virus like particles (VLPs) which use only the capsid of the viruses (35). In the following sections, some representative examples are discussed according to the targeted integrin subtype. 


\section{TARGETING $\alpha v \beta 3$ AND $\alpha v \beta 5$ INTEGRINS}

As previously introduced, the $\alpha v \beta 3$ integrin subtype plays a major role in angiogenesis, tumor neovascularization, and tumor metastasis (8). The angiogenic pathways dependent on $\alpha \mathrm{v} \beta 3$ have been described to be induced by bFGF or tumor necrosis factor $\alpha$ (TNF$\alpha)$. Its expression is upregulated on angiogenic endothelial cells (36-38) and on various tumor cell lines $(39,40)$. Antagonistic inhibition of $\alpha v \beta 3$ integrin has been shown to suppress angiogenesis (41) and to induce apoptosis (42). The well-established biological roles, high expression on tumor tissues, and the availability of ligands with high affinity, have set $\alpha v \beta 3$ the most extensively studied integrin for tumor targeting. The integrin $\alpha v \beta 5$ is also involved in angiogenesis but through a distinct pathway stimulated by VEGF or transforming growth factor $\alpha$ (TGF- $\alpha$ ) (16). Since most RGD-containing peptidic $\alpha \mathrm{v} \beta 3$ antagonists also recognize $\alpha v \beta 5$, although usually with a lower affinity, these two integrin subtypes are discussed together.

\section{TARGETED DELIVERY OF CHEMOTHERAPY USING POLYMERIC VEHICLES}

Encapsulation of drugs in polymer-based carrier systems is a practical approach to protect them from degradation in biological system. Furthermore, these systems may reduce the systemic toxicity of the drug and also enhance their safe elimination from the physiological system. In addition, these vehicles often ameliorate the drug's pharmacokinetic profile and biological distribution within the organism. Phospholipid or polypeptide-based polymers are commonly employed to prepare drug-delivery vehicles as they are akin to biological molecular components and thus display low toxicity and are easily biodegradable. Since the physicochemical properties of these polymers can be easily tuned to produce liposomes, micelles, or NPs, via well-established protocols, these materials are frequently used to construct drug-delivery vehicles. In fact, liposomes have already been used for the formulation and delivery of DOX (4). These vehicles may additionally be PEGylated to improve their aqueous solubility and to reduce non-specific interactions with plasma proteins and membranes. Besides encapsulation, drugs can as well be bound to these systems by chemical methods. This enables drug stability and also secured $\mathrm{pH}$-sensitive release of drugs in situ. These sorts of carrier systems have been equipped with integrin targeting ligands and experimented for their capabilities as targeted drug-delivery systems in cancer treatment. Some illustrative recent works are listed in Table 1.

\section{TARGETED DELIVERY OF CHEMOTHERAPY USING PROTEIN-BASED NPS}

Although polymer-based vehicle systems are a common choice for drug delivery, their long-term biological toxicity might be an issue and needs to be carefully assessed. For this reason, proteinbased NPs are considered an attractive alternative for targeted therapy due to their high biocompatibility, biodegradable properties, and water solubility. With regard to this, albumin is one of the proteins that has been most majorly explored for drug delivery. For example, linking $c$ (RGDyK)C to albumin NPs loaded with Gemcitabine showed an increased in vitro and in vivo antitumor efficacy in BxPC-3 pancreatic cancer cell lines compared to NPs without the targeting sequence (43). The conjugation of cyclic RGD to albumin not only lead to successful targeting but also increased the intracellular uptake of NPs and Gemcitabine as monitored by florescence studies. The $\alpha \mathrm{v} \beta 3$-mediated uptake of the RGD-conjugated components into pancreatic cells was further confirmed by competitive inhibition studies using soluble RGD ligands. In another study (44), Fluorouracil-bearing $c$ RGDfKalbumin nanospheres have shown significant improvement in binding to $\alpha v \beta 3$-expressing HUVEC cells in vitro. A considerable improvement in prevention of lung metastasis and angiogenesis, and in tumor regression was observed in vivo in B16F10 tumorbearing mice as compared with the activity of the free drug. The binding of nanospheres conjugated with RGD to endothelial cells was eightfold higher than that of nanospheres without RGD or conjugated with the RAD sequence (which does not bind to integrins). Similarly, enhanced homing to tumors and endothelial cell binding were reported for $c$ RGDfK-PEG-albumin NPs that were linked to the antimitotic agent monomethyl-auristatin-E (MMAE) (45). These studies were carried out on HUVECs and C26 carcinoma-bearing mice. Two kinds of target systems were prepared with an RGD peptide linked to albumin either by a PEG chain (RGD-PEG-MMAE-HSA) or a short alkyl chain (RGDMMAE-HSA). After IV administration in mice, fluorescent studies showed colocalization of both carrier systems with the tumor vasculature and tumor cells.

Besides the use of albumin as drug-delivery system, spider silk is a protein that holds great promise for application in targeted therapies. Due to its water solubility, excellent biocompatibility, and unique mechanical properties, spider silk has attracted growing interest in a number of biomedical areas. Spider silks are currently under investigation for the encapsulation and controlled release of drugs and growth factors, with so far optimistic outcomes (46). Scheibel's group has prepared spider silks containing the integrin recognition motifs GRGDSP or $c$ RGDfK by either recombinant expression or chemical methods, respectively (47). These RGD functionalized proteins have been used to generate spider silk films that retain the biophysical properties observed for silks prepared using the native proteins. Significant improvements in the attachment and proliferation of BALB/3T3 mouse fibroblasts were observed on films containing the RGD sequence but not on unmodified or RGE-containing silk. These results encourage further exploration of spider silk protein as a prospective carrier system for targeted drug delivery in cancer.

\section{TARGETED DELIVERY OF CHEMOTHERAPY USING METALLIC NPS}

Gold and other metallic NPs can be used for the polyvalent display of targeting scaffolds (48). Ease of preparation and functionalization as well as unique physicochemical properties make gold NPs very attractive systems for use in cancer diagnosis and therapy. For instance, PEGylated gold NPs coupled to a $c$ RGD peptidomimetic via thiol chemistry showed good affinity and binding to $\alpha v \beta 3$ positive PC-3 prostate cancer cells in vitro (49). In another study, Yang et al. have examined the utility of multifunctional PEGylated superparamagnetic iron oxide (SPIO) NPs in targeted drug delivery and PET/Magnetic Resonance Imaging (MRI) (50). To this end, $c$ RGDfC and a common ${ }^{64} \mathrm{Cu}$ chelator were bound to the distal ends of the PEG chains, whereas the drug, DOX, was conjugated to the SPIO particles via $\mathrm{pH}$-sensitive hydrazone bonds. 
Table 1 | Outline of representative recent examples of polymer-based targeted delivery studies using $\alpha \mathbf{v} \beta 3$ and/or $\alpha \mathbf{v} \beta 5$ integrin ligands.

\begin{tabular}{|c|c|c|c|c|}
\hline Carrier system & Targeting motif & Drug & Cellular system & Results and characteristics (reference) \\
\hline
\end{tabular}

MPEG2000

$\begin{array}{lll}\text { PLG-PEG micelles } \quad \text { cRGDFC DOX } & \text { U87MG human } \\ & \text { glioblastoma cells }\end{array}$

PLGA-4-arm-PEG CRGDFC $\quad$ - $\quad$ Pancreatic tumor in mice

branched NPs and U87MG glioma cells

\begin{tabular}{|c|c|c|c|}
\hline $\begin{array}{l}\text { PGA-PTX-E- } \\
{[c(\text { RGDfK)]2 }} \\
\text { conjugate NPs }\end{array}$ & cRGDfK & PTX & $\begin{array}{l}4 \mathrm{~T} 1 \text { murine breast cancer } \\
\text { tumors }\end{array}$ \\
\hline PLGA-PEG NPS & $\begin{array}{l}\text { GRGDS and RGD } \\
\text { peptidomimetic }\end{array}$ & PTX and DOX & $\begin{array}{l}\text { HUVECs and syngenic TLT } \\
\text { cells }\end{array}$ \\
\hline $\begin{array}{l}\text { cRGDyK-PEG- } \\
\text { PLA-PTX micelle }\end{array}$ & cRGDyK & PTX & $\begin{array}{l}\text { Intracranial glioblastoma } \\
\text { model }\end{array}$ \\
\hline
\end{tabular}

FOR OTHER STUDIES USING PLGA-PLL NPs PLEASE SEE REF. $(101,102)$

HPMA copolymers CRGDFK

Geldanamycin

PC-3 and DU145 prostate

cancer cell lines

\begin{tabular}{|c|c|c|c|}
\hline HPMA copolymers & cRGDfK & Docetaxel & $\begin{array}{l}\text { PC-3 and DU145 prostate } \\
\text { cancer cell lines }\end{array}$ \\
\hline $\begin{array}{l}\text { PCL-PEEP and } \\
\text { Mal-PEG-PCL } \\
\text { micelles }\end{array}$ & Tf and $c$ RGDfK & PTX & $\begin{array}{l}\text { BMEC and U87MG gliome } \\
\text { cells }\end{array}$ \\
\hline $\begin{array}{l}\text { HPAE-co-PLA/DPPE } \\
\text { polymer NPs }\end{array}$ & Tf and $c$ RGDfK & PTX & HUVECs and HeLa cells \\
\hline $\begin{array}{l}\text { PFC } \\
\text { (perfluorocarbon) } \\
\text { NPs }\end{array}$ & $\begin{array}{l}\text { Non-peptidic } \alpha \vee \beta 3 \\
\text { antagonist }\end{array}$ & Fumagillin & $\begin{array}{l}\text { Vx-2 adenocarcinoma } \\
\text { tumor }\end{array}$ \\
\hline $\begin{array}{l}P(P E G M E M A) \text { based } \\
\text { micelles }\end{array}$ & RGD & Albendazole & $\begin{array}{l}\text { OVCAR-3 ovarian cancer } \\
\text { cells }\end{array}$ \\
\hline
\end{tabular}

$\mathrm{pH}$-sensitive drug release, higher cellular uptake, higher accumulation at tumor sites as monitored by positron emission tomography (PET) and ex vivo fluorescence experiments (96)

Efficient uptake by U87MG glioma cells over-expressing $\alpha v \beta 3$. Highest accumulation at tumor site as monitored by whole body imaging. Low in vivo inherent physiological toxicity for the NPs (97)

Augmented antitumor activity and reduced systemic toxicity for PTX, blockade of endothelial cell migration to VEGF and adhesion to fibrinogen. Lysosomal enzyme assisted release of PTX is observed (98)

High cellular uptake in vitro, improved anticancer efficacy and higher survival rate of mice (99)

2.5-Fold increase in antiglioblastoma cell cytotoxicity effect over non-targeted system, improved drug accumulation, increase in life time of diseased mice (100)

Tumor growth inhibition activity as efficient as free drug, decrease in $I_{50}$ values for targeted conjugates. Improvements in biodistribution profile, both in vitro and in vivo antiangiogenic, and antitumor activities for targeted systems (103-105)

Inhibition of PC3, DU145 cell growth and also of HUVECs in vitro. In vivo tumor regression is also observed (106)

Double targeting by Tf and RGD ligand. Uptake of micelles increased 2.4 times for BMEC compared to micelles lacking Tf. High drug accumulation in brain upon IV injection (107)

In vitro cytotoxicity for NPs coated with $c R G D$ is increased 10 times in $\alpha v \beta 3$-expressing HUVECs while Tf targeting to Tf receptor over-expressed HeLa cells lead to twofold increase. $\mathrm{pH}$-sensitive intracellular drug release (108)

Diminished development of tumor neovasculature and reduced tumor growth are observed at much lower drug concentrations compared to the previous concentration used in rodent and human clinical trials (109)

Improved cellular uptake of polymeric micelles and $80 \%$ cell deaths at a micelle concentration of $10 \mu \mathrm{g} \mathrm{mL}^{-1}$ (110)
The $c$ RGD-conjugated SPIO nanocarriers exhibited higher cellular uptake and cytotoxicity in U87MG cells compared to $c$ RGD-free systems. Also, in vivo PET imaging of U87MG tumor-bearing mice revealed increased tumor accumulation of $c$ RGD-SPIO NPs compared to $c$ RGD-free counterparts. Intracellular specific drug release by SPIOs was facilitated by $\mathrm{pH}$-selective cleavage of the SPIO-DOX hydrazone linkage. Such multifunctional systems that are able to simultaneously target a cell or tissue, deliver a drug, and provide a diagnosis are known as theranostics, which constitute an upcoming area of research. 


\section{TARGETED DELIVERY OF GENE THERAPY}

Delivery of gene therapy using targeted non-viral vehicles has been widely studied (20). A directed delivery of DNA or RNA fragments is required to prevent from using high doses, which otherwise can lead to off-target gene silencing effects. Using carrier systems for gene therapy is advantageous as it reduces the problems of biodegradability, nucleosomal cleavage, and size and charge limited membrane impermeability associated with the delivery of nucleic acids. As mentioned earlier, non-viral vectors are also helpful to overcome complications and safety issues described for viral vectors. Here, we briefly tabulate some recent targeted gene therapy studies (Table 2).

Table 2 | Outline of recent targeted gene delivery studies using $\alpha \mathrm{v} \beta 3$ and/or $\alpha \mathrm{v} \beta 5$ integrin ligands.

\begin{tabular}{|c|c|c|c|c|}
\hline Carrier system & Targeting motif & Gene & Cellular system & Results and Characteristics (reference) \\
\hline $\begin{array}{l}\text { PEG-PLys polyplex } \\
\text { micelle }\end{array}$ & $c$ RGDfK & Luc-pDNA & HeLa cells and 293T cells & $\begin{array}{l}\text { Enhanced transfection efficiency (TE) and perinuclear } \\
\text { accumulation of pDNA within } 3 \mathrm{~h} \text { of incubation (111) }\end{array}$ \\
\hline $\begin{array}{l}\text { PEG-PLys polyplex } \\
\text { micelle: cross-linked } \\
\text { by thiolation }\end{array}$ & $c$ RGDfK & Luc-pDNA & HeLa cells and 293T cells & $\begin{array}{l}\text { Improvements in TE, selection of endocytotic pathways and } \\
\text { regulation of intracellular trafficking by } c R G D \text {. Preferential } \\
\text { caveolae mediated endocytosis is observed. Thiol } \\
\text { cross-linking helped polyplex stabilization and pDNA } \\
\text { protection (112) }\end{array}$ \\
\hline $\begin{array}{l}\text { PEG-PLys polyplex } \\
\text { micelle: cross-linked } \\
\text { by thiolation }\end{array}$ & $c$ RGDfK & sFlt-1 & $\begin{array}{l}\text { BxPC-3 pancreatic } \\
\text { adenocarcinoma tumors }\end{array}$ & $\begin{array}{l}\text { Upon IV injection, significant tumor-specific TE and gene } \\
\text { expression is observed which lead to a decrease in tumor } \\
\text { vasculature. Thiol cross-linking has to be optimized to } \\
\text { improve results }(113,114)\end{array}$ \\
\hline $\begin{array}{l}\text { PEG-PEI polyplex } \\
\text { micelles }\end{array}$ & $\begin{array}{l}\text { B6 peptide and } \\
\text { RGD bicyclo } \\
\text { peptide }\end{array}$ & pCMVLuc & $\begin{array}{l}\text { DU145 and PC3 prostate } \\
\text { cancer cells }\end{array}$ & $\begin{array}{l}\text { Significant improvement in TE via targeting. RGD helped in } \\
\text { initial association of polyplexes to cells whereas the } \\
\text { internalization is observed to be mediated by TfR } \\
\text { endocytosis (115) }\end{array}$ \\
\hline $\begin{array}{l}\text { PEG-PEI polyplex } \\
\text { micelles }\end{array}$ & $\begin{array}{l}\text { Non-cyclic RGD- } \\
\text { peptidomimetic }\end{array}$ & & MeWo and A549 cells & $\begin{array}{l}\text { Increased binding, uptake, and luciferase transgene } \\
\text { expression in model cells (116) }\end{array}$ \\
\hline $\begin{array}{l}\text { PEG-PEI polyplex } \\
\text { micelles }\end{array}$ & $c$ RGDyK & pORF-hTRAIL & $\begin{array}{l}\text { Intracranial U87 } \\
\text { glioblastoma tumor } \\
\text { xenografts }\end{array}$ & $\begin{array}{l}\text { Higher gene transfection and increased therapeutic } \\
\text { efficiency of TRAIL are observed and is reflected in } \\
\text { improved longevities of mice (117) }\end{array}$ \\
\hline $\begin{array}{l}\text { DNA/PEI-Au-RGD } \\
\text { nanoclusters }\end{array}$ & Cap-RGD & pEGFP-Luc & HeLa cells & $\begin{array}{l}\text { A 5.4- to 35-fold increase in TE corresponding to a low or } \\
\text { high density of } \alpha v \beta 3 \text { on HeLa cells. Observed TEs are far } \\
\text { higher than that for targeted or untargeted commercial } \\
\text { transfection vector - JetPEl. Higher concentration of gold } \\
\text { NPs is found to be toxic (118) }\end{array}$ \\
\hline $\begin{array}{l}\text { PEG-oligo(ethane } \\
\text { amino) amide } \\
\text { polymers }\end{array}$ & $\begin{array}{l}\text { B6 peptide or } \\
\text { cRGDfK }\end{array}$ & pEGFP-Luc & $\begin{array}{l}\text { Mouse N2A } \\
\text { neuroblastoma and DU145 } \\
\text { human prostate } \\
\text { adenocarcinoma cells }\end{array}$ & $\begin{array}{l}\text { Selective binding and transfection efficiency are observed } \\
\text { which are mediated by the targeting ligands. The carrier } \\
\text { systems however required use of endosomolytic agents for } \\
\text { release of polyplexes from endosomes (119) }\end{array}$ \\
\hline $\begin{array}{l}\text { DCP-TEPA } \\
\text { polycation liposomes }\end{array}$ & $c$ RGDfK & siLuc2 & $\begin{array}{l}\text { B16F10-luc2 murine } \\
\text { melanoma cells }\end{array}$ & $\begin{array}{l}\text { Successful targeting, transfection, and knockdown of luc2 } \\
\text { expression in vitro in B16F10-luc2 cells and also in vivo as } \\
\text { monitored by imaging in mice with tumor-bearing lungs, is } \\
\text { observed (120) }\end{array}$ \\
\hline PEO- $b$-PCL micelles & RGD4C & $\begin{array}{l}\text { mdr1 siRNA } \\
\text { and DOX }\end{array}$ & $\begin{array}{l}\text { MDA435/LCC6 cells } \\
\text { resistant to DOX }\end{array}$ & $\begin{array}{l}\text { The system is decorated with cell penetrating peptide (TAT) } \\
\text { as well. Dual functional micelles showed improved cellular } \\
\text { uptake and mdr1 activity leading to lowered P-gp expression } \\
\text { both at the mRNA and protein levels. These effects caused } \\
\text { reversal of MDR for DOX, which increased DOX } \\
\text { accumulation in cytoplasm and nucleus, and enhanced DOX } \\
\text { cytotoxicity (121) }\end{array}$ \\
\hline
\end{tabular}




\section{PHOTOTHERAPY USING TARGETED SYSTEMS}

Gormley et al. have tested the use of targeted gold nanorods (GNRs) for plasmonic photothermal therapy (PPTT) aiming at reducing the amount of heat required in thermal therapy (51). To this end, PEGylated GNRs were prepared and functionalized with $c$ RGDfK via thiol chemistry. Studies on HUVEC and DU145 prostate cancer cells showed effective in vitro selective targeting of RGD-GNRs to both these cell types but not in vivo in a DU145 mice model. The absence of in vivo effects was attributed to faster clearance of GNRs from physiological system due to the presence of negative charges in $c$ RGDfK-functionalized GNRs. On similar lines, for PPTT, Akhavan et al. have projected reduced single layer graphene oxide nanorods (GONRs) functionalized by amphiphilic PEG polymers containing RGDbased peptides (52). RGD-presenting GONRs showed increased radiation absorption compared to non-functionalized GONRs and also improved destruction of U87MG human glioblastoma cells at reduced doses as low as $1 \mu \mathrm{g} \mathrm{mL}^{-1}$. Irradiation for $8 \mathrm{~min}$ with near-infrared radiation at this concentration resulted in remarkable values of cell destruction $(\geq 97 \%)$. On the contrary, $<11 \%$ of cell destruction and $7 \%$ of DNA fragmentation were observed for non-targeted nanorods using the same concentration.

\section{TARGETING THE $\alpha 5 \beta 1$ INTEGRIN}

In addition to $\alpha v \beta 3$ and $\alpha v \beta 5$, an upregulated expression of $\alpha 5 \beta 1$ in tumor vasculature and other cancer cells has also been described (36, 53-57). $\alpha 5 \beta 1$ primarily recognizes fibronectin through the RGD binding motif. Kim et al. have reported that $\alpha 5 \beta 1$ inhibition induces cell apoptosis in endothelial cells (58) and also showed that this integrin mediates the migration of endothelial cells. Noteworthy, it has been shown that $\alpha 5$ might substitute the activity of $\alpha \mathrm{v}$ during vasculature remodeling (59). For these reasons, targeting of this integrin has also been approached in cancer therapy.

Kokkoli and co-workers have explored $\alpha 5 \beta 1$ integrin for targeting cancer cells by using a fibronectin mimetic $\alpha 5 \beta 1$-selective RGD-containing peptide, named PR_b (60) (Figure 2). This group produced DPPC-based liposomal NPs covered by PEG and further decorated with PR_b peptide, and studied their targeting capacity in a CT26.WT mouse colon carcinoma experimental model. The quantities of PEG and peptide were fine-tuned in order to optimize the delivery of the nanovector. By increasing the quantity of conjugated peptide, an enhancement in binding of liposomes to cells was observed, whereas the opposite effect was found when the concentration of PEG was augmented. The cytotoxicity of 5-Fluorouracil carried by these PR_b targeted liposomes was found to be comparable to that of the free drug and better than that of the particles containing only the control GRGDSP sequence, confirming the importance of targeting $\alpha 5 \beta 1$ on this cancer model. Similar results were obtained in studies using HCT116 and RKO human colon cancer cells (60). This liposomal system has been further investigated for the delivery and cytotoxicity of DOX to MDA-MB 231 breast cancer cells (61). Confocal microscopy experiments showed that these targeted liposomes were internalized in breast cancer cells via an endocytic pathway, and transferred within the first minutes into early endosomes, and after prolonged times into late endosomes and lysosomes. Particularly at high concentrations, the therapeutic effect of encapsulated DOX in MDA-MB 231 cells was comparable to that of the free DOX.

In a recent approach, PR_b targeted polymersomes have also been explored for siRNA delivery (62). T47D breast cancer cells were studied to check the expression of Orai3. The downregulation of Orai3 levels results in cell apoptosis. The delivery of Orai3 by PR_b-conjugated polymersomes decreased the viability of cancer cells but did not affect non-cancerous MCF10A breast cells. When compared to a commercial transfection agent (Lipofectamine RNAiMAX), the observed therapeutic effect of the polymersome formulation is still moderate. However, this method has not shown any systemic toxicity unlike other transfection reagents.

\section{TARGETING THE $\alpha v \beta 6$ INTEGRIN}

The integrin subtype $\alpha v \beta 6$ is expressed at low or undetectable levels in most adult epithelia, but may be upregulated during inflammation and wound healing (8). $\alpha \mathrm{v} \beta 6$ preferentially binds to TGF- $\beta 1$ latency associated peptide (LAP) (63), but can also recognize the ECM proteins tenascin and fibronectin (64). In this regard, $\alpha v \beta 6$ is biologically important for the activation of TGF$\beta 1$ and has been shown to control TGF- $\beta$ activity or signaling in fibrosis and to play a crucial role in TGF- $\beta$-integrin crosstalk in carcinomas (65). Furthermore, $\alpha v \beta 6$ was found to be significantly upregulated in tumor tissues (8) and in certain cancer types including colon (66), ovarian carcinoma (67), and in early stage of non-small cell lung cancer (NSCLC), which is associated with poor patient survival $(68,69)$. Other studies have shown that $\alpha v \beta 6$ expression is correlated with the development of metastasis in gastric cancer and the enhanced survival and invasive potential of carcinoma cells $(70,71)$. This pathological relevance has turned $\alpha v \beta 6$ into a promising target for tumor diagnostics and antitumor therapy.

To date, several linear and cyclic peptides as well as peptidomimetics have been developed to target specifically the $\alpha v \beta 6$ integrin subtype $(68,70,72-74)$. For instance, the high affinity $\alpha v \beta 6$-specific 20-mer peptide H2009.1 (75) was conjugated as a tetramer to a poly-glutamic acid polymer carrying DOX, and was shown to specifically target $\alpha v \beta 6$-expressing cells in vitro (76). In another work, the selectivity of this peptide toward $\alpha v \beta 6$ was exploited to guide fluorescent quantum dots to lung adenocarcinoma cell line H2009 in vitro (68). Recently, this peptide has also been conjugated to a water soluble PTX conjugate resulting in selective cytotoxicity for the $\alpha v \beta 6$-expressing NSCLC cell line (77). The conjugate was able to reduce the rate of tumor growth in vivo, however without an increased benefit over the use of free PTX. Furthermore, the same peptide was used to investigate the multimeric effect on functionalized liposomes (78). In this study, liposomes displaying tetramers of the H2009.1 peptide demonstrated higher drug delivery and toxicity toward $\alpha \mathrm{v} \beta 6$-expressing cells than liposomes displaying single copies of H2009.1, even if the total number of peptides bound to each liposome was identical. In another approach, H2009.1 was used to functionalize the surface of multifunctional micelles encapsulated with SPIO and DOX for MRI and drug-delivery applications, respectively (79). The functionalized micelles significantly increased cell targeting and uptake in $\alpha v \beta 6$-expressing $\mathrm{H} 2009$ cells, as verified by MRI and confocal imaging. 
A20FMDV2 $(80,81)$ is another $\alpha \mathrm{v} \beta 6$-selecitve 20-mer peptide (Figure 2) that can be used for targeted therapies. As an example, this peptide was radiolabeled on solid phase using 4$\left[{ }^{18} \mathrm{~F}\right]$ fluorobenzoic acid and the conjugate was selectively uptaken by $\alpha v \beta 6$-positive tumors but not by $\alpha v \beta 6$-negative tumors, as monitored in mice by PET (70). In a similar approach, A20FMDV2 was conjugated to 5 - $\left[{ }^{18} \mathrm{~F}\right]$ fluoro-1-pentyne via an azide-based 1,3dipolar cycloaddition (click chemistry). However, no difference in tumor targeting in vivo was observed for such strategy compared to the previous labeling method (82). ${ }^{18}$ F-labeled derivatives of the same peptide were described to improve tumor uptake capacity in BxPC-3 (pancreatic cancer) xenograft-bearing mice over $\left[{ }^{18} \mathrm{~F}\right]-\mathrm{FDG}$ (83). Recently, A20FMDV2 was conjugated to an ${ }^{18} \mathrm{~F}$-based tracer by copper-free, strain promoted click chemistry. However, the resulting derivative did not show a remarkable in vivo tumor uptake by mouse with mouse model DX3puro $\beta 6$ tumor (84). Furthermore, A20FMDV2 was conjugated to DTPA and labeled with ${ }^{111}$ In for SPECT imaging. In this study, the conjugate showed specific localization in $\alpha v \beta 6$-tissues, and displayed increased uptake in an $\alpha \mathrm{v} \beta 6$-positive tumor and in a mouse xenograft model bearing breast tumors that express $\alpha v \beta 6$ endogenously (85). Additionally, A20FMDV2 was incorporated into a recombinant adenovirus type 5 (Ad5) leading to increased cytotoxicity on a panel of $\alpha v \beta 6$-positive human carcinoma cell lines in vitro and enhancement in tumor uptake and improved tumor transduction in an $\alpha v \beta 6$-positive xenograft model in vivo over the Ad5 wild type (86).

In another approach pursued by the Gambhir research group, cystine knot peptides showing high affinity for $\alpha v \beta 6$ but none for the related subtypes $\alpha v \beta 3$, $\alpha v \beta 5$, and $\alpha 5 \beta 1$ were developed and conjugated to ${ }^{64} \mathrm{Cu}$-DOTA for PET-based tumor imaging (87). Injection of these conjugates into mice bearing either $\alpha v \beta 6$ positive BxPC-3 xenografts or $\alpha v \beta 6$-negative tumors, and monitoring by PET imaging, showed $\alpha v \beta 6$-selective targeting for the tumors expressing $\alpha v \beta 6$. In a recent study (88), two cystine knot peptides were labeled with ${ }^{18} \mathrm{~F}$-fluorobenzoate and their capacity to be uptaken by tumor cells assessed in vivo. PET imaging revealed for both peptides specific targeting of $\alpha v \beta 6$-positive BxPC-3 xenografted tumors over $\alpha v \beta 6$-negative HEK 293 tumors. These results illustrate the potential of the described strategies to be clinically used in PET imaging of $\alpha v \beta 6$-over-expressing tumors.

\section{CONCLUDING REMARKS}

A wide variety of carrier systems have been described to achieve tumor-specific therapeutic effects via integrin targeting. The principal success of this strategy is evidenced by two main observations - the dosage of drug has been usually reduced and an enhanced (and often selective) activity against tumors is achieved. The data obtained from independent studies using different carrier systems are promising and there is therefore hope to bring the targeted delivery methods into practice. However, a number of aspects related to the use of these drug-delivery systems in cancer therapy should be carefully considered.

In the first place, comparative studies between distinct carrier systems are missing. Such studies could provide useful insights on their relative advantages and disadvantages, and help in their further development and optimization. Detailed studies concerning the systemic toxicity and long-term side effects of the drug-delivery vectors in physiological systems are also essential. Another important aspect to optimize the concentration of drugs in cancer therapy would be to evaluate the efficiency of drug uptake with regard to the overall administered dose, but most studies have only rated the efficiency of the targeted systems in comparison to untargeted systems, without mentioning about the concentrations of the drug used. The investigation of the metabolic stability of these systems in gut and liver as well as their bioavailability profile would also be crucial to improve the efficacy of the therapy. Further optimization of such drug formulations could be directed toward new routes of administration, including, though certainly difficult, orally available conjugates.

It should be mentioned that most studies in this field rank the antitumor potency of the targeted systems based on the reduction in tumor volume and size, parameters that will however not entirely assure the success of the therapy. More satisfactory would be to carry out longer experiments to ensure the complete removal of tumors and arrest of resurrections. In this regard, recent findings have suggested that antiangiogenic therapeutics that aim at treating cancer primarily through reduction and control of tumor growth, may, in some cases, indirectly promote cancer invasiveness and metastasis $(89,90)$. This ultimately alarms development of targeted therapies which can inhibit multiple cellular functions and affecting not only cell survival in situ but also mechanisms involved in the promotion and progression of metastasis. Further investigations on this matter should include the study of targeted therapy on early stage and late stage tumors, and the effect (if any) of these strategies in the development of drug resistance mechanisms by some tumors. Additionally, treatment of cancer often necessitates a combination therapy (combination of different therapeutics or therapies). In this respect, it is demanding to study the usage of targeted approaches for delivering multiple drugs or therapies either by a single carrier system or multiple carrier systems. These studies are further pending in literature. Most of the studies on targeted gene delivery have used luciferase model system. Though it is a good analogous system for understanding gene delivery, proper experimental gene therapy studies aimed to treat cancers are to be extensively studied.

The choice of an optimal integrin ligand is another aspect of paramount importance in the design of integrin-based targeted therapies in cancer. This will depend on the differential pattern of integrin expression in cancer cell types and the biological activity and selectivity profiles of the targeting ligands. Many applications have used linear or cyclic RGD peptides to deliver drugs or nucleotides to tumors. Most of these peptides are active for $\alpha v \beta 3$; however, it is often ignored that these ligands may target other integrin subtypes as well. This might not be relevant as long as simplified cellular or experimental animal models are investigated. However, it may raise safety concerns if clinical applications in humans are to be envisaged. E.g., the habitually used peptide $-c$ (RGDfX), developed in our group long ago $(25,30)$, has about $1 \mathrm{nM}$ affinity for $\alpha \mathrm{v} \beta 3$ and is certainly selective against $\alpha \operatorname{IIb} \beta 3$ (low affinity for the platelet receptor). 
Nonetheless, the compound also has affinity in the low nanomolar range for $\alpha v \beta 5(7.6 \mathrm{nM})$ and $\alpha 5 \beta 1(15 \mathrm{nM})$ (73). Thus, the use of $c$ (RGDfX) might not always provide enough selectivity to distinguish between distinct cell types. In this regard, our group has recently developed $(91,92)$ and functionalized $(93,94)$ peptidomimetics which can clearly discriminate between $\alpha v \beta 3$ and $\alpha 5 \beta 1$. Application of such single integrin subtype selective ligands

\section{REFERENCES}

1. Kumar S, Mahdi H, Bryant C, Shah JP, Garg G, Munkarah A. Clinical trials and progress with paclitaxel in ovarian cancer. Int $J$ Womens Health (2010) 2:411-27. doi: 10.2147/IJWH.S7012

2. Weiss RB, Donehower RC, Wiernik PH, Ohnuma T, Gralla RJ, Trump DL, et al. Hypersensitivity reactions from taxol. J Clin Oncol (1990) 8:1263-8.

3. Prados J, Melguizo C, Ortiz R, Vélez C, Alvarez PJ, Arias $\mathrm{JL}$, et al. Doxorubicin-loaded nanoparticles: new advances in breast cancer therapy. Anticancer Agents Med Chem (2012) 12:1058-70. doi:10.2174/ 187152012803529646

4. Lao J, Madani J, Puértolas T, Álvarez M, Hernández A, PazoCid R, et al. Liposomal doxorubicin in the treatment of breast cancer patients: a review. J Drug Deliv (2013) 456409:1-12. doi:10. 1155/2013/456409

5. Bergman AM, Pinedo HM, Peters GJ. Determinants of resistance to 2'2'-difluorodeoxycytidine (gemcitabine). Drug Resist Updat (2002) 5:19-33. doi:10.1016/ S1368-7646(02)00002-X

6. Yusuf RZ, Duan Z, Lamendola DE, Penson RT, Seiden MV. Paclitaxel resistance: molecular mechanisms and pharmacologic manipulation. Curr Cancer Drug Targets (2003) 3:1-19. doi:10.2174/ 1568009033333754

7. Galletti E, Magnani M, Renzulli ML, Botta M. Paclitaxel and docetaxel resistance: molecular mechanisms and development of new generation taxanes. ChemMedChem (2007) 2:920-42. doi:10. 1002/cmdc.200600308

8. Desgrosellier JS, Cheresh DA. Integrins in cancer: biological implications and therapeutic opportunities. Nat Rev Cancer (2010) 10:922. doi:10.1038/nrc2748

9. Ruoslahti E. Specialization of tumour vasculature. Nat Rev Cancer (2002) 2:83-90. doi:10.1038/ nrc724

10. Teesalu T, Sugahara KN, Ruoslahti E. Mapping of vascular ZIP codes by phage display. Methods Enzymol
(2012) 503:35-56. doi:10.1016/ B978-0-12-396962-0.00002-1

11. Goodman SL, Picard M. Integrins as therapeutic targets. Trends Pharmacol Sci (2012) 33:405-12. doi:10.1016/j.tips.2012.04.002

12. Barczyk M, Carracedo S, Gullberg D. Integrins. Cell Tissue Res (2010) 339:269-80. doi:10.1007/ s00441-009-0834-6

13. Pierschbacher MD, Ruoslahti E. Cell attachment activity of fibronectin can be duplicated by small synthetic fragments of the molecule. Nature (1984) 309:30-3. doi:10.1038/309030a0

14. Cabodi S, Di Stefano P, Leal Mdel P, Tinnirello A, Bisaro B, Morello V, et al. Integrins and signal transduction. Adv Exp Med Biol (2010) 674:43-54. doi:10. 1007/978-1-4419-6066-5_5

15. Cox D, Brennan M, Moran N. Integrins as therapeutic targets: lessons and opportunities. Nat Rev Drug Discov (2010) 9:804-20. doi:10. 1038/nrd3266

16. Weis SM, Cheresh DA. $\alpha$ V integrins in angiogenesis and cancer. Cold Spring Harb Perspect Med (2011) 1:a006478. doi:10. 1101/cshperspect.a006478

17. Rathinam R, Alahari SK. Important role of integrins in the cancer biology. Cancer Metastasis $\operatorname{Rev}$ (2010) 29:223-37. doi:10. 1007/s10555-010-9211-x

18. Moschos SJ, Drogowski LM, Reppert SL, Kirkwood JM. Integrins and cancer. Oncology (Williston Park, N Y) (2007) 21:13-20.

19. Temming K, Schiffelers RM, Molema G, Kok RJ. RGD-based strategies for selective delivery of therapeutics and imaging agents to the tumour vasculature. Drug Resist Updat (2005) 8:381-402. doi:10.1016/j.drup.2005.10.002

20. Park J, Singha K, Son S, Kim J, Namgung R, Yun CO, et al. A review of RGD-functionalized nonviral gene delivery vectors for cancer therapy. Cancer Gene Ther (2012) 19:741-8. doi:10.1038/cgt. 2012.64

21. Danhier F, Le Breton A, Préat V. RGD-based strategies to target $\alpha v \beta 3$ integrin in cancer therapy and diagnosis. Mol Pharm

will enable a selective and controlled delivery of drugs to tumors, taking advantage of the distinct patterns of integrin expression found for each cancer type.

It is on the basis of these considerations that targeted therapy with integrin ligands be translated into clinical studies, and be demonstrated whether such strategy will result in a clear benefit for cancer patients.

(2012) 9:2961-73. doi:10.1021/ mp3002733

22. Chen K, Chen X. Integrin targeted delivery of chemotherapeutics. Theranostics (2011) 1: 189-200. doi:10.7150/thno/ v01p0189

23. Ruoslahti E. The RGD story: a personal account. Matrix Biol (2003) 22:459-65. doi:10.1016/ S0945-053X(03)00083-0

24. Meyer A, Auernheimer J, Modlinger A, Kessler H. Targeting RGD recognizing integrins: drug development, biomaterial research, tumor imaging and targeting. Curr Pharm Des (2006) 12:2723-47. doi:10.2174/138161206777947740

25. Aumailley M, Gurrath M, Müller G, Calvete J, Timpl R, Kessler H. Arg-Gly-Asp constrained within cyclic pentapeptides. Strong and selective inhibitors of cell adhesion to vitronectin and laminin fragment P1. FEBS Lett (1991) 291:50-4. doi:10.1016/00145793(91)81101-D

26. Chatterjee J, Gilon C, Hoffman A, Kessler H. N-methylation of peptides: a new perspective in medicinal chemistry. Acc Chem Res (2008) 41:1331-42. doi:10.1021/ ar8000603

27. Chatterjee J, Rechenmacher F, Kessler H. N-methylation of peptides and proteins: an important element for modulating biological functions. Angew Chem Int Ed Engl (2013) 52:254-69. doi:10. 1002/anie.201205674

28. Dechantsreiter MA, Planker E, Mathä B, Lohof E, Hölzemann G, Jonczyk A, et al. N-methylated cyclic RGD peptides as highly active and selective $\alpha v \beta 3$ integrin antagonists. J Med Chem (1999) 42:3033-40. doi:10.1021/ jm970832g

29. Mas-Moruno C, Rechenmacher F, Kessler H. Cilengitide: the first anti-angiogenic small molecule drug candidate design, synthesis and clinical evaluation. Anticancer Agents Med Chem (2010) 10:753-68. doi:10.2174/ 187152010794728639

30. Haubner R, Gratias R, Diefenbach B, Goodman SL, Jonczyk A, Kessler H. Structural and functional aspects of RGD-containing cyclic pentapeptides as highly potent and selective integrin $\alpha v \beta 3$ antagonists. J Am Chem Soc (1996) 118:746172. doi:10.1021/ja9603721

31. Koivunen E, Wang B, Ruoslahti E. Phage libraries displaying cyclic peptides with different ring sizes: ligand specificities of the RGDdirected integrins. Nat Biotechnol (1995) 13:265-70. doi:10.1038/ nbt0395-265

32. Hajitou A. Targeted systemic gene therapy and molecular imaging of cancer contribution of the vascular-targeted AAVP vector. Adv Genet (2010) 69:65-82. doi:10.1016/S0065-2660(10) 69008-6

33. Smaglik P. Merck blocks "safer" gene therapy trials. Nature (2000) 403:817. doi:10.1038/35002743

34. Edelstein ML, Abedi MR, Wixon J. Gene therapy clinical trials worldwide to 2007 - an update. J Gene Med (2007) 9:833-42. doi:10. 1002/jgm. 1100

35. Hovlid ML, Steinmetz NF, Laufer B, Lau JL, Kuzelka J, Wang Q, et al. Guiding plant virus particles to integrin-displaying cells. Nanoscale (2012) 4:3698-705. doi: $10.1039 / \mathrm{c} 2 \mathrm{nr} 30571 \mathrm{~b}$

36. Avraamides CJ, Garmy-Susini B, Varner JA. Integrins in angiogenesis and lymphangiogenesis. Nat Rev Cancer (2008) 8:604-17. doi: $10.1038 / \mathrm{nrc} 2353$

37. Brooks PC, Clark RA, Cheresh DA. Requirement of vascular integrin $\alpha v \beta 3$ for angiogenesis. Science (1994) 264:569-71. doi:10. 1126/science.7512751

38. Sipkins DA, Cheresh DA, Kazemi MR, Nevin LM, Bednarski MD, Li KC. Detection of tumor angiogenesis in vivo by $\alpha v \beta 3$-targeted magnetic resonance imaging. Nat Med (1998) 4:623-6. doi:10.1038/ nm0598-623

39. Beck V, Herold H, Benge A, Luber B, Hutzler $\mathrm{P}$, Tschesche $\mathrm{H}$, et al. ADAM15 decreases integrin $\alpha v \beta 3$ /vitronectin-mediated ovarian cancer cell adhesion and motility in an RGD-dependent fashion. Int J Biochem Cell Biol (2005) 37:590-603. doi:10.1016/j.biocel. 2004.08.005 
40. Chen X, Park R, Tohme M, Shahinian AH, Bading JR, Conti PS. MicroPET and autoradiographic imaging of breast cancer $\alpha v_{-}$ integrin expression using ${ }^{18} \mathrm{~F}$ - and ${ }^{64} \mathrm{Cu}$-labeled RGD peptide. Bioconjug Chem (2004) 15:41-9. doi: $10.1021 / \mathrm{bc} 0300403$

41. Brooks PC, Strömblad S, Klemke R, Visscher D, Sarkar FH, Cheresh DA. Antiintegrin $\alpha \mathrm{v} \beta 3$ blocks human breast cancer growth and angiogenesis in human skin. J Clin Invest (1995) 96:1815-22. doi:10. 1172/JCI118227

42. Meerovitch K, Bergeron F, Leblond L, Grouix B, Poirier C, Bubenik $\mathrm{M}$, et al. A novel RGD antagonist that targets both $\alpha \mathrm{v} \beta 3$ and $\alpha 5 \beta 1$ induces apoptosis of angiogenic endothelial cells on type I collagen. Vascul Pharmacol (2003) 40:77-89. doi:10.1016/ S1537-1891(02)00339-7

43. Ji S, Xu J, Zhang B, Yao W, $\mathrm{Xu} \mathrm{W}, \mathrm{Wu} \mathrm{W}$, et al. RGDconjugated albumin nanoparticles as a novel delivery vehicle in pancreatic cancer therapy. Cancer Biol Ther (2012) 13:206-15. doi:10. 4161/cbt.13.4.18692

44. Dubey PK, Singodia D, Verma RK, Vyas SP. RGD modified albumin nanospheres for tumour vasculature targeting. $J$ Pharm Pharmacol (2011) 63:33-40. doi:10.1111/j.2042-7158.2010. 01180.x

45. Temming K, Meyer DL, Zabinski R, Dijkers EC, Poelstra K, Molema G, et al. Evaluation of RGD-targeted albumin carriers for specific delivery of auristatin E to tumor blood vessels. Bioconjug Chem (2006) 17:1385-94. doi:10. 1021/bc060087z

46. Wenk E, Wandrey AJ, Merkle HP, Meinel L. Silk fibroin spheres as a platform for controlled drug delivery. J Control Release (2008) 132:26-34. doi:10.1016/j.jconrel. 2008.08.005

47. Wohlrab S, Müller S, Schmidt A, Neubauer S, Kessler H, Leal-Egaña A, et al. Cell adhesion and proliferation on RGD-modified recombinant spider silk proteins. Biomaterials (2012) 33:6650-9. doi:10. 1016/j.biomaterials.2012.05.069

48. Arnold M, Cavalcanti-Adam EA, Glass R, Blümmel J, Eck W, Kantlehner M, et al. Activation of integrin function by nanopatterned adhesive interfaces. Chemphyschem (2004) 5:383-8. doi:10.1002/cphc.200301014

49. Arosio D, Manzoni L, Araldi EM, Scolastico C. Cyclic RGD functionalized gold nanoparticles for tumor targeting. Bioconjug Chem (2011) 22:664-72. doi:10. $1021 / b c 100448 \mathrm{r}$

50. Yang X, Hong H, Grailer JJ, Rowland IJ, Javadi A, Hurley $\mathrm{SA}$, et al. cRGD-functionalized, DOX-conjugated, and $64 \mathrm{Cu}-$ labeled superparamagnetic iron oxide nanoparticles for targeted anticancer drug delivery and PET/MR imaging. Biomaterials (2011) 32:4151-60. doi:10.1016/j. biomaterials.2011.02.006

51. Gormley AJ, Malugin A, Ray A, Robinson R, Ghandehari H. Biological evaluation of RGDfK-gold nanorod conjugates for prostate cancer treatment. J Drug Target (2011) 19:915-24. doi:10.3109/ 1061186X.2011.623701

52. Akhavan O, Ghaderi E, Emamy H. Nontoxic concentrations of PEGylated graphene nanoribbons for selective cancer cell imaging and photothermal therapy. JMater Chem (2012) 22:20626-33. doi:10. 1039/c2jm34330d

53. Kim S, Bell K, Mousa SA, Varner JA. Regulation of angiogenesis in vivo by ligation of integrin $\alpha 5 \beta 1$ with the central cell-binding domain of fibronectin. Am J Pathol (2000) 156:1345-62. doi:10.1016/S00029440(10)65005-5

54. Kim S, Harris M, Varner JA. Regulation of integrin $\alpha v \beta 3$-mediated endothelial cell migration and angiogenesis by integrin $\alpha 5 \beta 1$ and protein kinase A. J Biol Chem (2000) 275:33920-8. doi:10.1074/ jbc.M003668200

55. Jayne DG, Heath RM, Dewhurst O, Scott N, Guillou PJ. Extracellular matrix proteins and chemoradiotherapy: $\alpha 5 \beta 1$ integrin as a predictive marker in rectal cancer. Eur J Surg Oncol (2002) 28:306. doi:10.1053/ejso.2001.1182

56. Jia Y, Zeng ZZ, Markwart SM, Rockwood KF, Ignatoski $\mathrm{KM}$, Ethier SP, et al. Integrin fibronectin receptors in matrix metalloproteinase-1-dependent invasion by breast cancer and mammary epithelial cells. Cancer Res (2004) 64:8674-81. doi:10. 1158/0008-5472.CAN-04-0069

57. Chen J, De S, Brainard J, Byzova TV. Metastatic properties of prostate cancer cells are controlled by VEGF. Cell Commun Adhes (2004) 11:1-11. doi:10.1080/15419060490471739

58. Kim S, Bakre M, Yin H, Varner JA. Inhibition of endothelial cell survival and angiogenesis by protein kinase A. J Clin
Invest (2002) 110:933-41. doi:10.1172/JCI0214268

59. van der Flier A, Badu-Nkansah K, Whittaker CA, Crowley D, Bronson RT, Lacy-Hulbert A, et al. Endothelial $\alpha 5$ and $\alpha v$ integrins cooperate in remodeling of the vasculature during development. Development (2010) 137:2439-49. doi:10.1242/ dev.049551

60. Garg A, Tisdale AW, Haidari E, Kokkoli E. Targeting colon cancer cells using PEGylated liposomes modified with a fibronectinmimetic peptide. Int $J$ Pharm (2009) 366:201-10. doi:10.1016/j. ijpharm.2008.09.016

61. Shroff K, Kokkoli E. PEGylated liposomal doxorubicin targeted to $\alpha 5 \beta 1$-expressing MDAMB-231 breast cancer cells. Langmuir (2012) 28:4729-36. doi:10. 1021/la204466g

62. Pangburn TO, Georgiou K, Bates FS, Kokkoli E. Targeted polymersome delivery of siRNA induces cell death of breast cancer cells dependent upon Orai3 protein expression. Langmuir (2012) 28:12816-30. doi:10.1021/la300874z

63. Munger JS, Huang X, Kawakatsu H, Griffiths MJ, Dalton SL, Wu J, et al. The integrin $\alpha v \beta 6$ binds and activates latent TGF beta 1: a mechanism for regulating pulmonary inflammation and fibrosis. Cell (1999) 96:319-28. doi:10.1016/ S0092-8674(00)80545-0

64. Plow EF, Haas TA, Zhang L, Loftus J, Smith JW. Ligand binding to integrins. $J$ Biol Chem (2000) 275:21785-8. doi:10.1074/ jbc.R000003200

65. Margadant C, Sonnenberg A. Integrin-TGF-beta crosstalk in fibrosis, cancer and wound healing. EMBO Rep (2010) 11:97-105. doi:10.1038/embor.2009.276

66. Bates RC, Bellovin DI, Brown C, Maynard E, Wu B, Kawakatsu $\mathrm{H}$, et al. Transcriptional activation of integrin $\beta 6$ during the epithelial-mesenchymal transition defines a novel prognostic indicator of aggressive colon carcinoma. J Clin Invest (2005) 115:339-47. doi:10.1172/JCI23183

67. Ahmed N, Pansino F, Baker M, Rice G, Quinn M. Association between $\alpha v \beta 6$ integrin expression, elevated p42/44 kDa MAPK, and plasminogen-dependent matrix degradation in ovarian cancer. $J$ Cell Biochem (2002) 84:675-86. doi:10.1002/jcb.10080

68. Elayadi AN, Samli KN, Prudkin L, Liu YH, Bian A, Xie XJ, et al.
A peptide selected by biopanning identifies the integrin $\alpha \mathrm{v} \beta 6$ as a prognostic biomarker for nonsmall cell lung cancer. Cancer Res (2007) 67:5889-95. doi:10.1158/ 0008-5472.CAN-07-0245

69. Prudkin L, Liu DD, Ozburn NC, Sun MH, Behrens C, Tang X, et al. Epithelial-to-mesenchymal transition in the development and progression of adenocarcinoma and squamous cell carcinoma of the lung. Mod Pathol (2009) 22: 668-78. doi:10.1038/modpathol. 2009.19

70. Hausner SH, DiCara D, Marik J, Marshall JF, Sutcliffe JL. Use of a peptide derived from foot-andmouth disease virus for the noninvasive imaging of human cancer: generation and evaluation of 4- $\left[{ }^{18} \mathrm{~F}\right]$ fluorobenzoyl A20FMDV2 for in vivo imaging of integrin av $\beta 6$ expression with positron emission tomography. Cancer Res (2007) 67:7833-40. doi:10.1158/ 0008-5472.CAN-07-1026

71. Kawashima A, Tsugawa S, Boku A, Kobayashi M, Minamoto T, Nakanishi I, et al. Expression of av integrin family in gastric carcinomas: increased $\alpha \mathrm{v} \beta 6$ is associated with lymph node metastasis. Pathol Res Pract (2003) 199:57-64. doi:10.1078/0344-0338-00355

72. Goodman SL, Hölzemann G, Sulyok GAG, Kessler H. Nanomolar small molecule inhibitors for $\alpha v \beta 6, \alpha v \beta 5$, and $\alpha v \beta 3$ integrins. J Med Chem (2002) 45:1045-51. doi:10.1021/jm0102598

73. Bochen A, Marelli UK, Otto E, Pallarola D, Mas-Moruno C, Di Leva FS, et al. Biselectivity of isoDGR peptides for fibronectin binding integrin subtypes $\alpha 5 \beta 1$ and $\alpha v \beta 6$ : conformational control through flanking amino acids. J Med Chem (2013) 56:1509-19. doi:10.1021/ jm301221x

74. Hsiao JR, Chang Y, Chen YL, Hsieh SH, Hsu KF, Wang CF, et al. Cyclic av $\beta 6$-targeting peptide selected from biopanning with clinical potential for head and neck squamous cell carcinoma. Head Neck (2010) 32:160-72. doi:10. 1002/hed.21166

75. Oyama T, Sykes KF, Samli KN, Minna JD, Johnston SA, Brown KC. Isolation of lung tumor specific peptides from a random peptide library: generation of diagnostic and cell-targeting reagents. Cancer Lett (2003) 202:219-30. doi:10.1016/j.canlet.2003.08.011

76. Guan H, McGuire MJ, Li S, Brown KC. Peptide-targeted 
polyglutamic acid doxorubicin conjugates for the treatment of $\alpha v \beta 6$-positive cancers. Bioconjug Chem (2008) 19:1813-21. doi:10.1021/bc800154f

77. Li S, Gray BP, McGuire MJ, Brown KC. Synthesis and biological evaluation of a peptidepaclitaxel conjugate which targets the integrin $\alpha \mathrm{v} \beta 6$. Bioorg Med Chem (2011) 19:5480-9. doi:10. 1016/j.bmc.2011.07.046

78. Gray BP, Li SZ, Brown KC. From phage display to nanoparticle delivery: functionalizing liposomes with multivalent peptides improves targeting to a cancer biomarker. Bioconjug Chem (2013) 24:85-96. doi:10.1021/bc300498d

79. Guthi JS, Yang SG, Huang G, Li SZ, Khemtong C, Kessinger $\mathrm{CW}$, et al. MRI-visible micellar nanomedicine for targeted drug delivery to lung cancer cells. $\mathrm{Mol}$ Pharm (2007) 7:32-40. doi:10. 1021/mp9001393

80. DiCara D, Rapisarda C, Sutcliffe JL, Violette SM, Weinreb PH, Hart IR, et al. Structure-function analysis of Arg-Gly-Asp helix motifs in $\alpha v \beta 6$ integrin ligands. J Biol Chem (2007) 282:9657-65. doi:10.1074/ jbc.M610461200

81. Logan D, Abughazaleh R, Blakemore W, Curry S, Jackson T, King A, et al. Structure of a major immunogenic site on footand-mouth disease virus. Nature (1993) 362:566-8. doi:10.1038/ $362566 \mathrm{a} 0$

82. Hausner SH, Marik J, Gagnon $\mathrm{MK}$, Sutcliffe JL. In vivo positron emission tomography (PET) imaging with an $\alpha \mathrm{v} \beta 6$ specific peptide radiolabeled using ${ }^{18} \mathrm{~F}$ - "click" chemistry: evaluation and comparison with the corresponding $4-\left[{ }^{18} \mathrm{~F}\right]$ fluorobenzoyl- and 2$\left[{ }^{18} \mathrm{~F}\right]$ fluoropropionyl-peptides. J Med Chem (2008) 51:5901-4. doi: $10.1021 / \mathrm{jm} 800608 \mathrm{~s}$

83. Hausner SH, Abbey CK, Bold RJ, Gagnon MK, Marik J, Marshall JF, et al. Targeted in vivo imaging of integrin $\alpha v \beta 6$ with an improved radiotracer and its relevance in a pancreatic tumor model. Cancer Res (2009) 69:5843-50. doi:10.1158/0008-5472.CAN-084410

84. Hausner SH, Carpenter RD, Bauer $\mathrm{N}$, Sutcliffe JL. Evaluation of an integrin $\alpha v \beta 6$-specific peptide labeled with $\left[{ }^{18} \mathrm{~F}\right]$ fluorine by copper-free, strain-promoted click chemistry. Nucl Med Biol (2013) 40:233-9. doi:10.1016/j. nucmedbio.2012.10.007
85. Saha A, Ellison D, Thomas GJ, Vallath S, Mather SJ, Hart IR, et al. High-resolution in vivo imaging of breast cancer by targeting the pro-invasive integrin $\alpha \mathrm{v} \beta 6 . J$ Pathol (2010) 222:52-63. doi:10. 1002/path. 2745

86. Coughlan L, Vallath S, Saha A, Flak M, McNeish IA, Vassaux G, et al. In vivo retargeting of adenovirus type 5 to $\alpha \mathrm{v} \beta 6$ integrin results in reduced hepatotoxicity and improved tumor uptake following systemic delivery. J Virol (2009) 83:6416-28. doi:10.1128/ JVI.00445-09

87. Kimura RH, Teed R, Hackel BJ, Pysz MA, Chuang CZ, Sathirachinda A, et al. Pharmacokinetically stabilized cystine knot peptides that bind $\alpha v \beta 6$ integrin with single-digit nanomolar affinities for detection of pancreatic cancer. Clin Cancer Res (2012) 18:839-49. doi:10.1158/10780432.CCR-11-1116

88. Hackel BJ, Kimura RH, Miao Z, Liu $\mathrm{H}$, Sathirachinda A, Cheng $\mathrm{Z}$, et al. ${ }^{18} \mathrm{~F}$-fluorobenzoate-labeled cystine knot peptides for PET imaging of integrin $\alpha \mathrm{v} \beta 6 . \mathrm{J} \mathrm{Nucl} \mathrm{Med}$ (2013) 54(7):1101-5. doi:10.2967/ jnumed.112.110759

89. Loges S, Mazzone M, Hohensinner P, Carmeliet P. Silencing or fueling metastasis with VEGF inhibitors: antiangiogenesis revisited. Cancer Cell (2009) 15:167-70. doi:10. 1016/j.ccr.2009.02.007

90. Shojaei F. Anti-angiogenesis therapy in cancer: current challenges and future perspectives. Cancer Lett (2012) 320:130-7. doi:10. 1016/j.canlet.2012.03.008

91. Heckmann D, Meyer A, Marinelli L, Zahn G, Stragies R, Kessler H. Probing integrin selectivity: rational design of highly active and selective ligands for the $\alpha 5 \beta 1$ and $\alpha \mathrm{v} \beta 3$ integrin receptor. Angew Chem Int Ed Engl (2007) 46: 3571-4. doi:10.1002/anie. 200700008

92. Heckmann D, Meyer A, Laufer B, Zahn G, Stragies R, Kessler H. Rational design of highly active and selective ligands for the $\alpha 5 \beta 1$ integrin receptor. Chembiochem (2008) 9:1397-407. doi:10.1002/ cbic. 200890032

93. Rechenmacher F, Neubauer S, Polleux J, Mas-Moruno C, De Simone M, Cavalcanti-Adam EA, et al. Functionalizing $\alpha v \beta 3$ - or $\alpha 5 \beta 1$-selective integrin antagonists for surface coating: a method to discriminate integrin subtypes in vitro. Angew Chem Int Ed
Engl (2013) 52:1572-5. doi:10. 1002/anie.201206370

94. Rechenmacher F, Neubauer S, Mas-Moruno C, Dorfner PM, Polleux J, Guasch J, et al. A Molecular toolkit for the functionalization of titanium-based biomaterials that selectively control integrinmediated cell adhesion. Chem Eur $J$ (2013) 19(28):9218-23. doi:10. 1002/chem.201301478

95. Murphy EA, Majeti BK, Barnes LA, Makale M, Weis SM, Lutu-Fuga K, et al. Nanoparticle-mediated drug delivery to tumor vasculature suppresses metastasis. Proc Natl Acad Sci U S A (2008) 105:9343-8. doi: 10.1073/pnas.0803728105

96. Xiao Y, Hong H, Javadi A, Engle JW, Xu W, Yang Y, et al. Multifunctional unimolecular micelles for cancer-targeted drug delivery and positron emission tomography imaging. Biomaterials (2012) 33:3071-82. doi:10.1016/j. biomaterials.2011.12.030

97. Ding H, Yong KT, Roy I, Hu R, Wu F, Zhao L, et al. Bioconjugated PLGA-4-arm-PEG branched polymeric nanoparticles as novel tumor targeting carriers. Nanotechnology (2011) 22:165101. doi: 10.1088/0957-4484/22/16/165101

98. Eldar-Boock A, Miller K, Sanchis J, Lupu R, Vicent MJ, Satchi-Fainaro R. Integrin-assisted drug delivery of nano-scaled polymer therapeutics bearing paclitaxel. Biomaterials (2011) 32:3862-74. doi:10.1016/j. biomaterials.2011.01.073

99. Danhier F, Vroman B, Lecouturier N, Crokart N, Pourcelle $\mathrm{V}$, Freichels $\mathrm{H}$, et al. Targeting of tumor endothelium by RGD-grafted PLGA-nanoparticles loaded with paclitaxel. J Control Release (2009) 140:166-73. doi:10. 1016/j.jconrel.2009.08.011

100. Zhan C, Gu B, Xie C, Li J, Liu Y, Lu W. Cyclic RGD conjugated poly(ethylene glycol)-copoly(lactic acid) micelle enhances paclitaxel anti-glioblastoma effect. J Control Release (2010) 143:13642. doi:10.1016/j.jconrel.2009.12. 020

101. Liu P, Qin L, Wang Q, Sun Y, Zhu M, Shen M, et al. cRGDfunctionalized mPEG-PLGA-PLL nanoparticles for imaging and therapy of breast cancer. Biomaterials (2012) 33:6739-47. doi:10. 1016/j.biomaterials.2012.06.008

102. Yin P, Wang Y, Qiu Y, Hou L, Liu X, Qin J, et al. Bufalin-loaded mPEGPLGA-PLL-cRGD nanoparticles: preparation, cellular uptake, tissue distribution, and anticancer activity. Int J Nanomedicine (2012) 7:3961-9. doi:10.2147/IJN.S32063

103. Borgman MP, Ray A, Kolhatkar RB, Sausville EA, Burger AM, Ghandehari H. Targetable HPMA copolymeraminohexylgeldanamycin conjugates for prostate cancer therapy. Pharm Res (2009) 26:1407-18. doi:10.1007/s11095-009-9851-0

104. Borgman MP, Aras O, GeyserStoops S, Sausville EA, Ghandehari H. Biodistribution of HPMA copolymeraminohexylgeldanamycin-

RGDfK conjugates for prostate cancer drug delivery. Mol Pharm (2009) 6:1836-47. doi:10.1021/mp900134c

105. Greish K, Ray A, Bauer H, Larson $\mathrm{N}$, Malugin A, Pike $\mathrm{D}$, et al. Anticancer and antiangiogenic activity of HPMA copolymeraminohexylgeldanamycin-

RGDfK conjugates for prostate cancer therapy. J Control Release (2011) 151:263-70. doi:10.1016/j.jconrel.2010.12.015

106. Ray A, Larson N, Pike DB, Grüner $M$, Naik S, Bauer $H$, et al. Comparison of active and passive targeting of docetaxel for prostate cancer therapy by HPMA copolymer-RGDfK conjugates. Mol Pharm (2011) 8:1090-9. doi: $10.1021 / \mathrm{mp} 100402 \mathrm{n}$

107. Zhang P, Hu L, Yin Q, Feng L, Li Y. Transferrin-modified c[RGDfK]paclitaxel loaded hybrid micelle for sequential blood-brain barrier penetration and glioma targeting therapy. Mol Pharm (2012) 9:1590-8. doi:10.1021/mp200600t

108. Xu Q, Liu Y, Su S, Li W, Chen C, Wu Y. Anti-tumor activity of paclitaxel through dual-targeting carrier of cyclic RGD and transferrin conjugated hyperbranched copolymer nanoparticles. Biomaterials (2012) 33:1627-39. doi:10. 1016/j.biomaterials.2011.11.012

109. Winter PM, Schmieder AH, Caruthers SD, Keene JL, Zhang H, Wickline SA, et al. Minute dosages of $\alpha v \beta 3$-targeted fumagillin nanoparticles impair $\mathrm{Vx}-2$ tumor angiogenesis and development in rabbits. FASEB J (2008) 22:275867. doi:10.1096/fj.07-103929

110. Kim Y, Pourgholami MH, Morris DL, Stenzel MH. An optimized RGD-decorated micellar drug delivery system for albendazole for the treatment of ovarian cancer: from RAFT polymer synthesis to cellular uptake. Macromol Biosci (2011) 11:219-33. doi: 10.1002/mabi.201000293 
111. Oba M, Fukushima S, Kanayama $\mathrm{N}$, Aoyagi K, Nishiyama N, Koyama $\mathrm{H}$, et al. Cyclic RGD peptideconjugated polyplex micelles as a targetable gene delivery system directed to cells possessing $\alpha v \beta 3$ and $\alpha v \beta 5$ integrins. Bioconjug Chem (2007) 18:1415-1123. doi:10.1021/bc0700133

112. Oba M, Aoyagi K, Miyata K, Matsumoto Y, Itaka K, Nishiyama $\mathrm{N}$, et al. Polyplex micelles with cyclic RGD peptide ligands and disulfide cross-links directing to the enhanced transfection via controlled intracellular trafficking. Mol Pharm (2008) 5:1080-92. doi: $10.1021 / \mathrm{mp} 800070 \mathrm{~s}$

113. Oba M, Vachutinsky Y, Miyata K, Kano MR, Ikeda S, Nishiyama N, et al. Antiangiogenic gene therapy of solid tumor by systemic injection of polyplex micelles loading plasmid DNA encoding soluble flt1. Mol Pharm (2010) 7:501-9. doi: $10.1021 / \mathrm{mp} 9002317$

114. Vachutinsky Y, Oba M, Miyata K, Hiki S, Kano MR, Nishiyama N, et al. Antiangiogenic gene therapy of experimental pancreatic tumor by sFlt-1 plasmid DNA carried by RGD-modified crosslinked polyplex micelles. J Control Release (2011) 149:51-7. doi:10.1016/j. jconrel.2010.02.002

115. Nie Y, Schaffert D, Rödl W, Ogris M, Wagner E, Günther M. Dual-targeted polyplexes: one step towards a synthetic virus for cancer gene therapy. J Control Release (2011) 152:127-34. doi:10.1016/j. jconrel.2011.02.028

116. Merkel OM, Germershaus O, Wada CK, Tarcha PJ, Merdan T, Kissel T. Integrin $\alpha \mathrm{v} \beta 3$ targeted gene delivery using RGD peptidomimetic conjugates with copolymers of PEGylated poly(ethylene imine). Bioconjug Chem (2009) 20:127080. doi:10.1021/bc9001695

117. Zhan C, Meng Q, Li Q, Feng L, Zhu J, Lu W. Cyclic RGD-polyethylene glycolpolyethylenimine for intracranial glioblastoma-targeted gene delivery. Chem Asian J (2012) 7:91-6. doi:10.1002/asia.201100570

118. Ng QK, Sutton MK, Soonsawad P, Xing L, Cheng H, Segura T. Engineering clustered ligand binding into nonviral vectors: $\alpha v \beta 3$ targeting as an example. Mol Ther (2009) 17:828-36. doi:10.1038/mt. 2009.11

119. Martin I, Dohmen C, MasMoruno C, Troiber C, Kos P, Schaffert D, et al. Solid-phaseassisted synthesis of targeting peptide-PEG-oligo(ethane amino)amides for receptormediated gene delivery. Org Biomol Chem (2012) 10:3258-68. doi:10.1039/c2ob06907e

120. Yonenaga N, Kenjo E, Asai T, Tsuruta A, Shimizu K, Dewa T, et al. RGD-based active targeting of novel polycation liposomes bearing siRNA for cancer treatment. J Control Release (2012) 160:17781. doi:10.1016/j.jconrel.2011.10. 004

121. Xiong XB, Uludag H, Lavasanifar A. Virus-mimetic polymeric micelles for targeted siRNA delivery. Biomaterials (2010) 31:588693. doi:10.1016/j.biomaterials. 2010.03.075

Conflict of Interest Statement: The authors declare that the research was conducted in the absence of any commercial or financial relationships that could be construed as a potential conflict of interest.

Received: 15 July 2013; paper pending published: 25 July 2013; accepted: 13 August 2013; published online: 30 August 2013.

Citation: Marelli UK, Rechenmacher F, Sobahi TRA, Mas-Moruno C and Kessler $H$ (2013) Tumor targeting via integrin ligands. Front. Oncol. 3:222. doi: 10.3389/fonc.2013.00222

This article was submitted to Pharmacology of Anti-Cancer Drugs, a section of the journal Frontiers in Oncology.

Copyright (c) 2013 Marelli, Rechenmacher, Sobahi, Mas-Moruno and Kessler. This is an open-access article distributed under the terms of the Creative Commons Attribution License (CC BY). The use, distribution or reproduction in other forums is permitted, provided the original author(s) or licensor are credited and that the original publication in this journal is cited, in accordance with accepted academic practice. No use, distribution or reproduction is permitted which does not comply with these terms. 